Article

\title{
Coloured BIPV Technologies: Methodological and Experimental Assessment for Architecturally Sensitive Areas
}

\author{
Martina Pelle ${ }^{1,2} \mathbb{C}$, Elena Lucchi ${ }^{1, *}$, Laura Maturi $^{1}$, Alexander Astigarraga ${ }^{1}$ \\ and Francesco Causone ${ }^{2}$ (D) \\ 1 Institute for Renewable Energy, EURAC Research, 29100 Bolzano, Italy; martina.pelle@eurac.edu (M.P.); \\ laura.maturi@eurac.edu (L.M.); alexander.astigarraga@eurac.edu (A.A.) \\ 2 Department of Energy, Politecnico di Milano, Via Lambruschini 4, 20156 Milano, Italy; \\ francesco.causone@polimi.it \\ * Correspondence: elena.lucchi@eurac.edu; Tel.: +39-0471-055-653
}

Received: 20 June 2020; Accepted: 20 August 2020; Published: 1 September 2020

\begin{abstract}
Energy flexibility in buildings is gaining momentum with the introduction of new European directives that enable buildings to manage their own energy demand and production, by storing, consuming or selling electricity according to their need. The transition towards a low-carbon energy system, through the promotion of on-site energy production and enhancement of self-consumption, can be supported by building-integrated photovoltaics (BIPV) technologies. This paper investigates the aesthetic and technological integration of hidden coloured PV modules in architecturally sensitive areas that seem to be the best possibility to favour a balance between conservation and energy issues. First, a multidisciplinary methodology for evaluating the aesthetic and technical integration of PV systems in architecturally sensitive area is proposed, referring to the technologies available on the market. Second, the experimental characterisation of the technical performance specific BIPV modules and their comparison with standard modules under standard weather condition are analysed, with the aim of acquiring useful data for comparing the modules' integration properties and performance. For this purpose, new testbeds have been set up to investigate the aesthetic integration and the energy performances of innovative BIPV products. The paper describes the analyses carried out to define the final configuration of these experimental testbeds. Finally, the experimental characterisation at standard test conditions of two coloured BIPV modules is presented and the experimental design for the outdoor testing is outlined.
\end{abstract}

Keywords: building-integrated photovoltaics; BIPV; hidden coloured BIPV module; BIPV integration; photovoltaic; PV

\section{Introduction}

The latest surveys on the current energy use scenario in Europe reported that buildings account for almost $40 \%$ of energy consumptions and $36 \%$ of carbon dioxide emissions ( $\mathrm{CO}_{2}$ emissions) [1]. The European Union (EU) has adopted a comprehensive regulatory framework to meet the commitments stated in the Paris Agreement [2] and to facilitate the transition from fossil fuels to cleaner energy production. The Energy Performance of Buildings Directive (EPBD) and the European Directive on Energy Efficiency (EED) provide the roadmap for the transformation of the existing building stock into nearly zero-energy buildings (nZEB) $[3,4]$ through the definition of specific measures to improve the energy efficiency of buildings, reduce the energy use and enhance the decarbonisation in the construction sector. Furthermore, the recast version of the Renewable Energy Directive [5] set the target for renewable energy source (RES) penetration in the European energy mix to $32 \%$ by 2030. Energy 
flexibility in buildings is, moreover, gaining momentum through the introduction of self-consumers and collective self-consumers concepts in regulations which, on the one hand, empower users to be prosumers instead of merely consumers and, on the other hand, enable buildings to manage their energy demand and production, by storing, consuming or selling electricity according to their need $[5,6]$. In this context, building integrated photovoltaics (BIPV) technologies can support the transition towards a low-carbon energy system, promoting on-site energy production and enhancing self-consumption, if integrated into the overall building/district energy system and coupled with electric or thermal storages [7]. BIPV constitute indeed a solution to incorporate RES in the built environment by integrating solar photovoltaics (PV) technologies in the building envelope. More precisely, BIPV systems have a dual purpose: they serve as building envelope and as power generation systems at the same time, harvesting solar energy for on-site energy production [8]. This is a relevant characteristic, especially for the decarbonisation of energy systems in densely built environments, where the on-site energy production is difficult to exploit due to urban constraints, which hinder traditional ground-mounted PV installation. In addition, the solar potential for roof-mounted PV is low if compared to multi-property and multi-story building energy demand [9]. Despite the high potential for BIPV applications, there is the need to overcome technical, social and economic barriers to reach a larger scale of BIPV applications, improving their economic profitability [10-12]. Besides the cost, which has consistently decreased recently, the main limit to the spread of BIPV has so far been their aesthetic, since they are often considered anaesthetic by users and architects [13]: "[ ... ] When we hear about photovoltaics, however, the image that is invoked in our mind is a blue or black element that usually seems to "overload" the aesthetic image of a building [14]. Research institutes, universities and industries are working together to design and produce a novel generation of BIPV solutions which will transform the visual appearance of standard PV modules into a more "architecturally pleasing" one [15] to be integrated into sensitive environments. Crystalline silicon modules, thin films, coloured solar cells, homogenised black appearance and integration of high-resolution images are just a few examples of the new possibilities offered by the PV market. However, the turning point in the acceptance of BIPV applications has been the development of hidden coloured BIPV modules. This module typology (which includes several different technologies, as discussed in Section 4) can hide the PV cells behind coloured patterns which hinder the perception of the original material of the cells. In this way, the modules appear very similar to standard construction materials [9]. As a result, a wide range of colours is currently available on the market, and this wide selection enables PV to be integrated also in traditional roofs, façades, and shading systems (Section 4). Nonetheless, the production of these modules is predominantly customisable for a specific installation. Modules customisation ensure a variety of new aesthetic and technical possibilities that facilitate the use of BIPV technologies also in densely built environments. This solution appears appropriate also for architecturally sensitive areas (i.e., historical centres, vernacular and historic buildings, natural and cultural landscapes), thanks to the aesthetical and technological advances related to low-rate reflection, mimetic appearance, compact shape and geometric flexibility [16-19]. Thus, these aesthetic improvements unlock the solar potential of a large set of vertical and horizontal envelope surfaces currently not exploited, leading the building stock to energy flexibility and self-sufficiency [20,21]. Conversely, the extreme requirements of customisation results in a fragmented market scenario and a high variety of colours, shapes, sizes, finishing, mechanical robustness and electricity generation efficiencies. Therefore, there is an urgent need to better frame the hidden coloured BIPV technologies available on the market, while building a common dialectic within the stakeholders along the entire value chain, to boost the BIPV market penetration. Section 2 indicates the aims and methodology pursued in this paper and outlines its structure.

\section{Aims and Methodology}

This paper investigates the aesthetic and technological integration of hidden coloured PV modules in architecturally sensitive areas. In these areas, there is an increasing debate on the possible integration of PV systems, respecting heritage constraints as well as preserving historic and natural values. 
Coloured BIPV modules seem the best possibility to favour a balance between conservation and energy issues (Section 4.1). In parallel, these technologies have shown a relatively recent market growth, and their applications are significantly increasing due to their flexibility. Therefore, there is an urgent need to better understand the overall technical performance of these promising products against the real requirements of the built environment, with the purpose of providing better modelling of their behaviour and fostering energy flexibility in buildings [22,23]. Despite the high technological readiness level (TRL) of BIPV systems, it is essential to further investigate their performance and reliability in operational environment to increase the users' trust and boost its market penetration.

One aspect related to the novelty of this research concerns the interdisciplinarity between aesthetic and technical aspects. The first one refers mainly to the work of conservators, designers, heritage and public authorities that need clear criteria for the methodological assessment of BIPV systems in architecturally sensitive areas. The second one refers to engineers, manufactures, supplies, installers and power utilities that need clear data from BIPV experimental assessment. For this reason, the paper is divided in two parts. First, a multidisciplinary methodology for evaluating the aesthetic and technical integration of PV systems in architecturally sensitive area is proposed, referring to the most promising technology (Sections 3 and 4). More precisely, in Section 3, the key concept of integration is discussed, with particular focus on the international guidelines for the application of BIPV in architecturally sensitive areas, which has been crucial to identifying the criteria for ensuring the aesthetic integration of BIPV technologies (Section 3.1). Then, once recognising that the visual integration is fundamental for broader BIPV deployment, and in particular that the geometrical uniformity and the colour of the cells play a key role in this respect, the analysis focuses on the state of the art of the existing technologies for hidden coloured PV modules. To this purpose, a deep technical review of the BIPV technological solutions available on the market is realised (Section 4). On these bases, an evaluation matrix has been developed with the aim of steering the market analysis required to choose the technologies to be tested within the project (Section 4.1). This evaluation process has been used to identify a set of different coloured BIPV technologies for their experimental characterisation. Second, the experimental characterisation of the technical performance specific BIPV modules and their comparison with standard modules under standard weather condition are analysed, with the aim of acquiring useful data for comparing the modules' integration properties and performance (Section 5). To this purpose, a new facility specifically developed for BIPV system has been set up for investigating the aesthetic integration and the energy performances of innovative PV products, focusing on the three integration concepts: (i) technology (i.e., innovative integration substructures); (ii) aesthetic (i.e., appealing PV modules); and (iii) energy integration (i.e., plug and play concepts). The description of the experimental facilities is provided in Section 5.1.1 (outdoor testbeds) and Section 5.1.2 (indoor laboratory). In Section 5.2, the indoor experimental results are presented, while the experimental design of the outdoor testbeds and the first qualitative results of the experimental camping is provided in Section 5.3. Finally, Section 6 presents the conclusions and lesson learnt. These facilities also allow to tackle specific challenges of BIPV to develop better and more performing systems, as well as to show among all the stakeholders involved in the value chain (i.e., manufactures, designers, supplies, installers, national public authorities, local planning authorities, power utilities, owners, final users and financial bodies) the benefits offered by these innovative BIPV panels.

This work has been made in the framework of the research project BIPV UPpeal that aims at accelerating BIPV market penetration by showing to the main stakeholders the benefit of integrating PV systems in architecturally sensitive areas. This permits to concretely show the new aesthetic and technical possibilities of BIPV systems (e.g., with testbeds, case studies and databases) but also to create a network among the professionals. Otherwise, innovative coloured BIPV technologies are selected to be tested in these testbeds following the evaluation criteria defined in the framework of the EU project BIPV meets history that aims at creating a value chain for the use of BIPV in heritages, according to the international guidelines and ad hoc working tables [19]. 


\section{PV Integration Concepts}

Scientific literature adopted several definitions of BIPV, avoiding a univocal consensus for the PV and the building sectors. PV modules are considered integrated by the standard EN 50583-1:2016 [24] are if "[ ... ] they form a construction product providing a function", as defined in the European Construction Product Regulation CPR 305/2011 [25]. This definition refers mainly to the idea of multi-functionality, according to which a BIPV module must have additional functions for the building envelope, besides the energy production (e.g., structural integrity; thermal insulation; solar shading; daylighting control; noise, fire and weather protection; safety; and security). However, this definition of BIPV does not seem exhaustive [15]. Different working groups of the International Energy Agency (IEA) on BIPV (i.e., PVPS Task 7 [15], IEA Task 41 [26], Task 59 [27] and Task 51 [28]), have underlined the importance of "formal/aesthetic" integration, beyond the multi-functionality concept. Particularly, the IEA-SHC Task 41 [26] defines architectural integration quality as the result of a controlled and coherent integration of the solar collectors from functional, constructive and formal (or aesthetic) points of view simultaneously. Other IEA working groups (Task 59 [27] and Task 51 [28]) also encourage an ad-hoc BIPV design to preserve original shapes, features and values in heritage and existing sites, favouring the aesthetic integration too. The balance of technical and aesthetic aspects is indeed a priority for BIPV system in terms of architectural functionalities and construction requirements (e.g., visual impact, dimensional flexibility, colour selection, easy mounting, safety and reliability, fire security, climate resistance, hygrothermal risks, thermal stability, maintenance and durability) $[19,29]$. From the analysis of the literature and standard definitions of BIPV, three integration levels can be identified [30]: (i) aesthetic; (ii) technological/functional; and (iii) energy (see Figure 1). Aesthetic integration refers to the capability of the PV solution to be included in the linguistic and morphological rules governing building's architectural language. The technological/functional level is strictly connected to the standard EN 50,583 definition [24], referring to the PV system capability to replace traditional building components. Finally, the energy integration refers to the ability of PV to be efficiently integrated into the overall energy system of the building/district through the "energy-matching" approach [31], thus interacting with the building loads to maximise self-consumption towards the implementation of efficient energy communities.

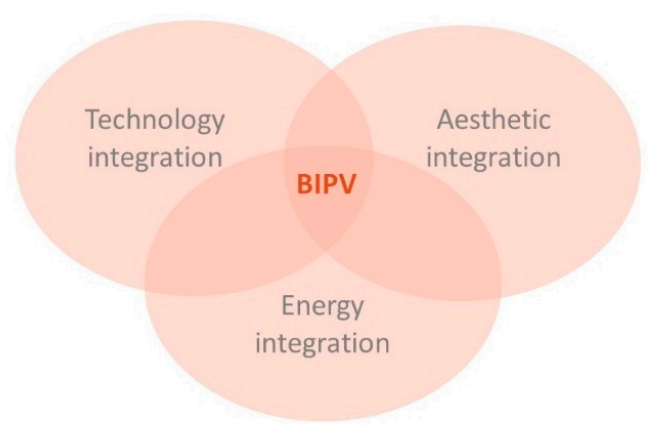

Figure 1. Multilevel BIPV integration aspects.

\subsection{PV Integration in Architecturally Sensitive Areas}

Special care must be given to PV integration in historical and heritage buildings as well as in architecturally and naturally sensitive areas (e.g., historical centres, heritage sites, archaeological areas or heritage landscapes). Consequently, several countries published national guidelines defining the architectural criteria for RES installation [32-38] according to national legislation, local authorisation processes and specific heritage features. These tools are addressed to the specialists in the field of design, architecture, engineering and energy consulting as well as to the public authorities involved in the energy issues, preservation of monuments and release of building permits [34]. The criteria for PV installation are always devoted to the protection of historic and distinctive materials, features, spaces, finishes, construction techniques, traditional craftsmanship and spatial relationships. Therefore, 
PV panels must not create permanent losses or transformations in the historic fabric, significant architectural obstructions or disjointed and multi-roof solutions [32-35,37,39]. Both PV and BIPV technologies can be inserted on new constructions, deteriorated historic buildings or elements (i.e., a damaged roof), non-historic buildings, new additions or adjacent constructions, while matching the original designs, colours and texture $[32,33,35,39]$. Missing features of historical buildings can also be replaced with PV panels or BIPV systems by documentary and physical evidence, using similar colours and textures [35,39]. PV technologies can also be used in industrial buildings and 20th century architecture, where they express the idea of "material innovation" [39]. In listed buildings and their settings, the heritage authorities must evaluate the impact of PV systems on the historic and natural values $[33,35,36,39]$.

According to the theory of restoration in architecture, the evaluation criteria in these sensitive areas can be summarised in visibility, technical compatibility and reversibility of the systems [34]. Visibility is the most important aspect in heritage buildings and natural areas. It refers to the minimisation of the visual impact of PV technologies, and thus the preservation of the original features, colours, texture, shapes, geometries, proportions and spatial relationships [33,35,39]. Overall, PV panels are not permitted on roofs and façades on the side of the building which is the most viewed generally from a public thoroughfare, a road or natural site or above the principal elevation [32,35]. On the contrary, PV panels can be located on hidden roof planes, for example in internal valley or street, behind parapets, new additions or outbuilding [35]. In this case, the new roof has to be hidden with existing roof ridge lines and flush [35]. Two main aesthetical parameters are considered for the integration of PV systems in architecturally sensitive areas: geometrical uniformity and colours of the cells. First, the visual impact of PV panels depends on the coverage of the surface by PV modules where $100 \%$ coverage is preferable for a more uniform appearance [32]. Therefore, BIPV products may be appropriately suited for historic buildings [35,39]. The acceptability of PV technologies is more difficult in these contexts because it requires also the respect of building lines, the grouping of PV panels, the reduction of the spaces among the panels and the accurate design [32,33,35,38-41]. Second, the chromatic integration with traditional materials is strongly suggested for PV camouflage, using terra-cotta cells for clay roof tiles, anthracite or green-grey cells for slate or stone, white cells for plaster or high-resolution images as marble or wood [39]. The aspects related to low-reflectance, camouflage of the PV cells, texturization and aesthetic pattern of PV modules are not considered in these guidelines but are very important for heritage authorities [19]. Compatibility refers to the protection of the integrity of the property and its environment guaranteeing the technical compatibility between old and new materials, avoiding hygrothermal (e.g., moisture accumulation on the back-side), structural (e.g., falling and excessive deflection) and energy (e.g., reduction of the efficiency and thermal bridges) risks [35]. Reversibility refers to the possibility of removing PV or BIPV system in the future, without affecting the essential form and integrity of the historic property and its environment. Removals and replacements of PV panels should be considered in the design phase to minimise loss or damage of original fabric [32]. The previous guidelines report only general principles for the aesthetic and technical integration of PV systems, but not references to specific technologies. On the contrary to these guidelines, some Italian working tables of the EU project BIPV meets history show that the heritage authority prefers BIPV systems instead of PV modules applied to a building element (i.e., roof or façade) or traditional material with PV panels (i.e., PV tile) [19]. Hidden coloured PV modules, semi-transparent PV-active layers and/or textured PV modules seem very promising for the integration in heritage and architecturally sensitive areas [19].

\section{Existing Technologies for Hidden Coloured PV Modules}

Broader architectural application claims for improvements in the aesthetic rendering of BIPV modules [23,42,43]. The turning point in the aesthetic acceptance of BIPV applications has been the development of modules that can hide the PV cells behind coloured patterns which hinder the perception of the original material of the cells, making the modules appear as standard construction 
components. This kind of coloured BIPV modules have shown relatively recent market growth, and their application is considerably increasing. Nonetheless, colouring the modules hinders the PV performance, due to the optical and physical behaviour of the coloured layers, which can cause the reflection of portions of solar radiation that would be otherwise converted into electricity [44]. Some theoretical studies, focusing mainly on monochromatic colours, were conducted to define the relations between the modules' colour and their power losses. The research highlighted a rather low level of power loss ranging between $7 \%$ and $10 \%$ [45]. However, BIPV applications imply a wider colour range and the finishing layer could present textures, uneven surfaces, fouling and time-related performance decay. Hence, there is the need to improve the awareness on coloured BIPV technologies with regards to the electrical behaviour of a large variety of coloured modules, which should guarantee reliable power output during their operation. Different customisation techniques to obtain coloured or textured BIPV modules are currently used for modules available on the market, including: (i) solar cells with anti-reflection coating; (ii) semi-transparent and/or coloured PV-active layers; (iii) layers or interlayers containing solar filters, coloured or patterned coatings; (iv) coloured polymeric encapsulant films; and (v) printed, coated or alternative finished front glass [46,47]. Hereafter, a brief overview of these technologies is provided. The study is not exhaustive, but it aims at defining the peculiarities of each typology in terms of technical potential for each category. The same nomenclature used in this section is reported in Table 1 to categorise some commercial products that have been considered in the frame of the BIPV market analysis (Section 4.1).

\subsection{Solar Cells with Anti-Reflection Coating}

Coloured solar cells can be produced by means of deposition on the cells' surface of a hydrogenated amorphous silicon nitride $\mathrm{SiN}_{\mathrm{x}}: \mathrm{H}$ layer, which serves for both passivation and antireflection coating (ARC). $\mathrm{SiN}_{\mathrm{x}}: \mathrm{H}$ layer is deposited by means of plasma-enhanced chemical vapour deposition [48]. Once this nitride layer is optimised in thickness and refractive index, solar cells assume the classic blue hue of standard PV modules. Other production techniques of the passivation and ARC are possible, using, for example, double anti-reflective coating (DARC) realised by electron beam (e-beam) evaporation techniques to deposit an additional layer of $\mathrm{SiO}_{2}$ on the $\mathrm{SiN}_{\mathrm{x}}: \mathrm{H}$ layer. Various colours can be obtained by tuning the $\mathrm{SiO}_{2}$ layer thickness, without any variation on the coloured solar cells' conversion efficiency $[49,50]$. Even if a quite large range of colours can be obtained by using this process (blue, yellow, bronze, green and purple), the coloured cells appear to be iridescent and highly variable with viewing angle and incident light polarisation [51].

\subsection{Semi-Transparent and/or Coloured Pv-Active Layers}

Coloured or semi-transparent PV-active layers can exhibit semi-transparency or colour tunability according to the absorption spectrum of the specific materials used as active layer. In this technology category organic solar cells (OSCs), dye-sensitised solar cells (DSSCs) and perovskite solar cells (PSCs) are included [52]. Distinct colour appearance in OSCs can be obtained, for example, by varying the materials used in the donor-acceptor combinations or adding coloured dye compounds to the active layer. In PSCs, colour tuning is imputable to band gap modification or the inclusion of dyes in the photoactive layer or other layers (e.g., hole transporting layer) [53]. The colours achievable through these techniques are manifold, but the system efficiency is affected by the optical behaviour of the coloured layer.

\subsection{Layers or Interlayers Containing Solar Filters, Coloured or Patterned Coatings}

Another option to obtain coloured BIPV modules is by using layers or interlayers containing solar filters, coloured or patterned coatings $[47,54]$, that can be laminated into the modules. In addition, encapsulant components and/or back sheet layers can be coloured or printed with semi-transparent ink. The degree of customisation for this BIPV typology is very high, and, consequently, the efficiency is highly affected by the optical properties of the coloured/patterned layers. 
Table 1. Commercially available BIPV products, divided by typology: (i) solar cells with anti-reflection coating; (ii) semi-transparent or coloured PV-active layers; (iii) layers or interlayers containing solar filters, coloured or patterned coatings; (iv) coloured polymeric encapsulant films; and (v) printed, coated or alternative finished front glass.

\begin{tabular}{|c|c|c|c|c|c|c|c|c|c|c|c|}
\hline \multicolumn{3}{|c|}{ Commercial Information } & \multicolumn{3}{|c|}{ Functional/Technological Integration } & \multicolumn{4}{|c|}{ Aesthetic Integration } & \multicolumn{2}{|c|}{ Energy Integration } \\
\hline Product & Producer & Typology & $\begin{array}{c}\text { Technological } \\
\text { Unit }\end{array}$ & $\begin{array}{c}\text { Technical } \\
\text { Element Class }\end{array}$ & Flexibility & Shape & $\begin{array}{l}\text { Dimension } \\
{[\mathrm{mm}]}\end{array}$ & Colour & Reflectance & Efficiency $[\%]$ & $\begin{array}{c}\text { Nominal } \\
\text { Power } \\
{\left[\mathrm{Wp} / \mathrm{m}^{2}\right]}\end{array}$ \\
\hline $\begin{array}{l}\text { Coloured solar } \\
\text { cells }\end{array}$ & LOF Solar & $\mathrm{i}$ & Multifunctional & Multifunctional & High & Rectangular & Custom & $>10$ & na & $14.5-18$ & $120-165$ \\
\hline Colorblast & Kameleon Solar & $\mathrm{v}$ & Multifunctional & Multifunctional & High & Custom & Custom & $\sim 6000$ & na & $8-15$ & $80-150$ \\
\hline Kromatix & SwissINSO & $\mathrm{v}$ & Multifunctional & Multifunctional & High & Rectangular & $\begin{array}{c}1000 \times 1640 \\
664 \times 1587\end{array}$ & Custom & $<20 \%$ & $11.9-18$ & $120-285$ \\
\hline Kaleo & CSEM & iii & Multifunctional & Multifunctional & High & Rectangular & Custom. & Custom & na & $\begin{array}{l}\text { Depending on } \\
\text { coverage }\end{array}$ & na \\
\hline $\begin{array}{l}\text { Solaris Heritage } \\
\text { (tile) }\end{array}$ & Freesuns & $\mathrm{v}$ & Roofing system & Roof & Medium & Rectangular & Custom. & 2 & na & up to 12.8 & $131-156$ \\
\hline Solaxess & Solaxess & iii & Multifunctional & Multifunctional & High & Custom & Custom & 5 & na & 11-15 & $106-147$ \\
\hline Solarskin & Sistine solar & $\mathrm{v}$ & Roofing system & Roof & Medium & Rectangular & na & Custom & na & $\begin{array}{l}\text { Depending on } \\
\text { coverage }\end{array}$ & na \\
\hline DSD-PV & $\begin{array}{l}\text { Dutch Solar } \\
\text { Design }\end{array}$ & iii & Multifunctional & Multifunctional & High & & $900 \times 1200 \mathrm{~mm}$ & Custom & na & $\begin{array}{l}\text { Depending on } \\
\text { coverage }\end{array}$ & na \\
\hline Suncol ${ }^{\circledR}$ uniform & $\begin{array}{l}\text { Glassfer \& } \\
\text { Sunage }\end{array}$ & $\mathrm{v}$ & Multifunctional & Multifunctional & High & Custom. & Custom & $>15$ & na & $12.7-15$ & $90-250$ \\
\hline Suncol ${ }^{\circledR}$ texturing & $\begin{array}{l}\text { Glassfer \& } \\
\text { Sunage }\end{array}$ & $\mathrm{v}$ & Multifunctional & Multifunctional & High & Custom. & Custom & Custom & na & $\begin{array}{l}\text { Depending on } \\
\text { coverage }\end{array}$ & $90-250$ \\
\hline InvisibleCell ${ }^{\circledR}$ & Invent & $\mathrm{v}$ & Multifunctional & Multifunctional & High & Rectangular & $997 \times 1663$ & Custom & na & $\begin{array}{l}\text { Depending on } \\
\text { coverage }\end{array}$ & 162 \\
\hline $\begin{array}{c}\text { Coloured } \\
\text { amorphous silicon } \\
\text { PV glass }\end{array}$ & Onyx solar & iv & Multifunctional & Multifunctional & High & Rectangular & Custom & Custom & na & na & $28-58$ \\
\hline Soltech Facade & Soltech & ii & Multifunctional & Multifunctional & High & Rectangular & $1200 \times 600$ & 4 & na & $1.2-11.2$ & na \\
\hline ClearVue PV (LSC) & ClearVue PV & iv & Multifunctional & Multifunctional & High & Rectangular & Custom & various & na & 3 & na \\
\hline Solar Roof Tiles & Tesla & $\mathrm{v}$ & Roofing system & Roof & Medium & Rectangular & $381 \times 1143$ & various & na & 10 & na \\
\hline
\end{tabular}




\subsection{Coloured Polymeric Encapsulant Films}

Polymer materials are usually used in the lamination process as a bonding and protective layer for semiconductors. The most frequent polymers used for this purpose are polyvinyl butyral (PVB) and Ethylene-vinyl acetate (EVA) [55]. Both these polymers can be manufactured in different colours and shades, and, when coupled with amorphous silicon or polycrystalline silicon PV, they lead to coloured PV modules with different degree of transparency and a quite large colour palette (coloured polymeric encapsulant films) [56]. To avoid undesired reflection or absorption of energy in the visible spectrum range, which could lead to the reduction in the efficiency of the modules, the coloured layer is usually provided at the rear side of the PV module [57].

\subsection{Printed, Coated or Alternative Finished Front Glass}

Modified front glass modules are produced by coupling a glass front sheet with a glass or metal back-sheet by means of lamination with polymeric encapsulants which incorporate c-Si cells. The most common encapsulant materials are ethylene-vinyl acetate (EVA) and polyvinyl butyral (PVB). The front glass sheets can be tinted with different hue or digitally printed to reproduce the appearance of traditional construction materials or any other pattern or image. This procedure ensures the camouflage of the PV cells which are almost completely hidden to the view. The front glass can be also texturized to provide different finishing [58]. Available finishing options on the market are shining, matte or three-dimensional texturized. Although the manifold customisation options offer several aesthetical advantages, the modification of the front glass leads to changes in the optical behaviour of the glass sheet, which could reflect or absorb a portion of the solar spectrum that would otherwise reach the PV cells where it would be used to produce electricity. Hence, the main challenge to be faced in the production of such modules consists in seeking the optimal trade-off between aesthetic and energy efficiency [44,45].

\subsection{Evaluation Criteria and Market Analysis}

As just reported, BIPV applications claim for multi-functionality properties of the products. The methodology for the evaluation and selection of a BIPV module for a defined project could ground its theoretical roots on this multi-functional integration (as defined in Section 1), identifying the requirements to be satisfied from the three integration levels identified in the literature and standards definition of BIPV (Section 3). The differences in the products of the market and the multifaced technical solutions could make module selection complex for the designer, who needs to be properly provided with the information required to support the design of the three integration aspects. Therefore, in this section, a specific methodology for selecting the BIPV systems in architecturally sensitive areas is proposed. The described methodology guided the selection of two technologies to be installed and tested in the outdoor testbed, in the frame of a broader experimental campaign on coloured BIPV products (see Section 5). The methodology consist in four steps: (i) the identification of three integration levels for BIPV systems (Section 3); (ii) the identification of specific parameters for defining the main characteristics of each integration level, according to the standard UNI 8290-1/2; (iii) the market analysis on commercial hidden coloured PV modules; and (iv) the comparison of different technologies, considering technical elements, flexibility, shapes, dimensions, colours and nominal power.

Once the three integration levels were identified and defined, specific parameters were identified for each of them, with the aim of drawing up an evaluation matrix that served as a base for the selection of the BIPV technologies. Then, a deep market analysis was performed to detect the existing technologies suitable for the experimental campaign. The parameter referred to each integration level are described in detail hereafter, while the results of the market analysis including the analysed technologies are presented in Table 1.

The functional or technological integration refers to the ability of the modules to serve as a building component, thus fulfilling the functional requirements handed over by the original building element. 
Typical envelope functions could be rain, snow, wind and solar protection, mechanical strength and reliability, shadowing or daylight admission. In Italy, the UNI 8290-1/2 [59] standard identifies for each technical element (i.e., roof, opaque vertical façade and transparent vertical façade) the corresponding requirements to be satisfied by the envelope components. Since the choice of a BIPV technology to be integrated into the building envelope must consider the functional requirements needed for the selected application, we decided to evaluate BIPV technologies according to the UNI 8290-1/2 [59] classification. Nonetheless, it is common to utilise a single BIPV product (typically coloured c-Si BIPV modules) for different applications by choosing the appropriate mounting system, e.g., as roof tiles or external layer of a ventilated façade. This peculiarity could grant to BIPV products a certain level of flexibility that facilitates the standardisation of the products manufacturing and the procurement design. This aspect has been considered through the identification of flexibility as a specific parameter for the functional integration in the evaluation matrix. As Table 1 highlights, the large variety of modules available on the market reflects the need of flexibility and multi-functionality and enables the use of the same module as elements belonging to a different technical class unit, if coupling with a suited mounting structure. Both multi-functionality and flexibility could be relevant characteristics for enhancing the market penetration of BIPV modules, since they enable the industrial production in series of a larger number of units that would eventually be used as different construction elements. This could represent an important advantage for BIPV industries, since it could potentially reduce the time and the costs of the modules production, encouraging BIPV market penetration.

The aesthetic integration identifies the ability of the product to define morphological and architectural rules which steer the architectural language and composition of buildings [26]. Consequently, the shape, dimension, position, materials, colour and texture of modules are defined in parallel with junction systems and mounting structure, which should be invisible to guarantee a good camouflage of the BIPV technology in the building envelope. The aesthetic evaluation is performed through four main parameters: (i) module's dimension; (ii) shape, defining the morphological integration of the BIPV technology in the building envelope; (iii) colour, which ensures the mimicking of the traditional building envelope material, camouflaging the BIPV module into the building envelope; and (iv) the module's reflectance, which is an essential aspect to be considered to ensure a high-quality aesthetic result and to avoid glare and overheating in the surroundings. As shown in Table 1, the first three parameters are quite common in the producers' specifications, while it is rare to find information about the module's reflectance. Furthermore, the market analysis highlights a common practice within the BIPV producers to provide customised solutions, mainly in terms of dimensions and colours. This is due to the peculiarity if the BIPV applications that, being tailored on the building envelopes, quite often require a specific design for the modules. This high level of customisation on the one hand constitutes the strength and the uniqueness of BIPV products in the PV scene, while on the other hand represents a limit since it hinders the series production of the modules limiting their cost reduction. In addition, the improvements of the BIPV industry in terms of available modules colours, which can range among an impressive hue palette and printing, are remarkable.

The energy integration refers to the ability of BIPV plants to interact with the energy systems at the building level or at the district level, with the aim of maximising the self-consumption. In fact, BIPV products could be used extensively on façades, enlarging the envelope surfaces available for PV installation. As a result, BIPV could lead to a shift in the energy paradigm for buildings: buildings would no longer be a mere energy consumer in the local electric grid, but it could indeed provide load flexibility, by producing, storing and selling electricity to the grid according to mutual needs. At present, within this paper, two preliminary parameters are evaluated in respect to the energy integration, i.e., the module's efficiency and its nominal power per square meter. This information is not easy to find on the producers' technical sheets since they are highly dependent on the chosen colour or texture. Table 1 shows some efficiency and nominal power range which have been retrieved both from technical documentation (if available) or directly from the producers, by means of interviews. In future studies, the "energy integration" concept will be more deeply investigated, since the PV 
Integration Lab is conceived to allow experiments on several "energy integration" configurations (i.e., stand alone, grid connected and plug and play). This way, the PV production can be associated to specific building loads (electrical consumption).

As stated before, multifunctionality and flexibility are relevant characteristics for enabling the use of the same BIPV technology in different technical elements, when coupled with the appropriate mounting structure. For this reason, modules' multifunctionality and high flexibility are prioritised in the selection of the technologies involved in the experimental campaign. Consequently, the technologies suited only for roofing systems have been discarded (Table 1). The architectural applications require larger aesthetical possibilities to ensure flexibility in the design. Thus, the customisation of modules' shapes and dimensions is important in architecturally sensitive areas, even if the standardisation of these characteristics would imply advantages for industrial series production. Therefore, we select the technologies that allow the customisation of shape and dimension. the same considerations are applied to colours. Producers that guarantee colour customisation or larger colour palette have been preferred. Then, among those, the producers that provided the higher modules' nominal power $\left(\mathrm{W} / \mathrm{m}^{2}\right)$ have been selected. As a result of this procedure, two BIPV technologies from Glassfer \& Sunage producer have been selected. Among the available colours and customised printed patterns, two module typologies suitable for the installation in sensitive architectural areas have been chosen. Both technologies present a modified front glass. The first one has a tinted front glass in a uniform "terracotta" colour, which is representative of the typical chromatic palette of Italian historical roofs (similar RAL 8015). The second one has a textured front glass, which reproduces the pattern of the terracotta Portuguese tiles through ceramic ink printing. Portuguese tiles are the most used typology of clay roof tile in vernacular and traditional Italian architecture as well as in historical towns.

\section{Experimental Characterisation of BIPV Technologies}

As emerged in H2020 Project PV IMPACT [60], BIPV stakeholders workshops, there is an urgent need by architects and designers to acquire more knowledge on coloured modules, to better understand the current possibilities on the market (as provided in Table 1) and to gather information on their performance and reliability. Although a broad literature exists on the theoretical relationship between colour and efficiency/power generation [44,45], there is a lack of information on the real final performance of coloured modules due to the fragmented techniques used by different PV modules producers. In fact, during the module assembling and the lamination process, the colour could change significantly compared to the initial components colour, obtaining different aesthetical solutions in the final product.

When standard modules became mainstream many scientific publications covered and shared test results, which helped to gain a greater understanding on the topic [61-63]. In this section, a similar approach is chosen to fill the knowledge gap about the technical characterisation at module level of coloured BIPV products in the scientific community. In fact, when it comes to the characterisation of coloured PV modules, several studies analysed coloured glass at material and optical level, while few analysed the electric behaviour of PV coloured modules ready for the market. Among the latter, those available assessed the modules' performance through outdoor tests $[58,64]$. Therefore, the experimental characterisation of BIPV modules is needed both at standard test conditions (STC) and under real operating conditions. For this reason, the project BIPV UPpeal aims at testing several BIPV products in the EURAC Research facilities in the next years. The overarching aim of the research is to test different BIPV technologies to collect useful information for comparing the technical properties of different modules. To do so, at first, the modules will be tested in the indoor laboratories at STC to characterise the performance according to the existing standard procedures. Then, the modules will be tested in the outdoor facilities, under real exposure conditions, to gain information on the dynamic behaviour of the modules under operating conditions in terms of energy performance, functional adequacy and aesthetical appealing. Hereafter, we provide a brief description of the experimental facilities that will be used within the research (Section 5.1) and we present the results of the first 
experimental indoor campaign (Section 5.2). Then, the description of the experimental design of outdoor testing is provided (Section 5.3).

\subsection{Experimental Facilities Description}

\subsubsection{Outdoor Facilities}

The selected modules will be mounted on the testbeds of the PV Integration Lab of EURAC Research (Figure 2). It consists of an outdoor infrastructure which allows testing and evaluating in real conditions the three aspects of BIPV integration: aesthetics, technology and energy. The roof testbed is a rotating roof measuring 20 square metres. It permits tilting up to $60^{\circ}$ from the horizontal plane and orienting in any direction to reproduce any exposure condition or any type of cover for roofs. The façade testbed consists of a vertical substructure of about 30 square meters that can host BIPV modules with any mounting systems. The testbeds are connected to a monitoring system for recording the electrical and environmental parameters (such as yield, solar radiation, air temperature and relative humidity) and the energy performance of any type of PV module. The BIPV systems can be connected to storage systems and/or the grid to verify the impact on electricity networks.

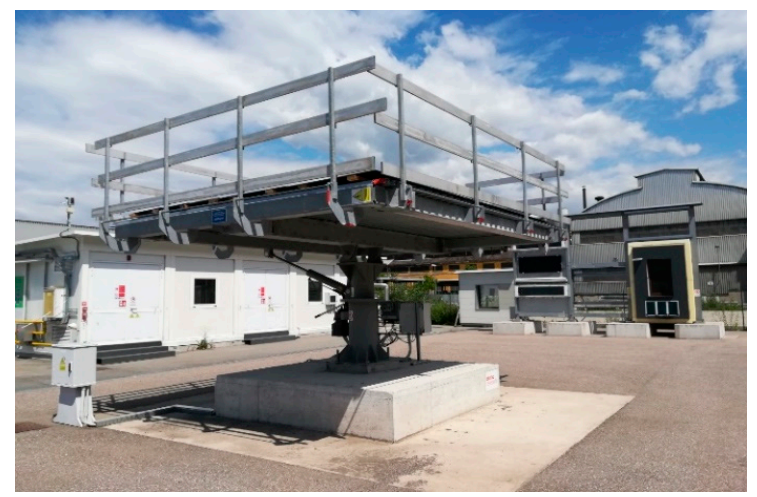

(a)

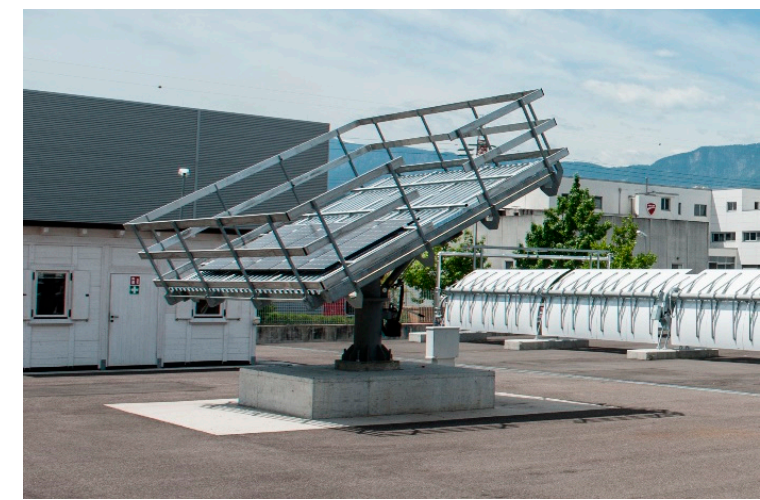

(b)

Figure 2. Outdoor PV integration lab: (a) view of roof in horizontal configuration and façade testbeds; and $(\mathbf{b})$ detail of rotating configuration of the of the roof testbed.

\subsubsection{Indoor Laboratory}

The indoor characterisation of BIPV modules is performed by means of the solar simulator (Figure 3a) and electroluminescence (EL) camera (Figure 3b) provided by indoor "Solare PV Lab" of EURAC Research. The pulsed light solar simulator is in class "AAA", according to the international standard IEC 60904-9 [65]. It measures the electrical performance of PV modules, allowing the performance analysis of a PV cell or the comparison among different technologies in controlled conditions. It measures the PV module's IV curve under standard conditions [65]. The measurements detect the energy performance of the module in different combinations of irradiance $\left(0-1000 \mathrm{~W} / \mathrm{m}^{2}\right)$ and temperature $\left(5-75^{\circ} \mathrm{C}\right)$ and its temperature coefficients, in accordance with UNI CEI EN ISO/IEC 17025:2005 [66]. The test accredited is the Performance at STC (MQT 06.1) for PV modules according to the standard IEC 61215:2016 [67]. The electroluminescence camera is a VIS-SWIR InGaAs camera with a quantum efficiency over $60 \%$ at $1-1.2 \mu \mathrm{m}$ and sensor of $640 \times 512$ pixels. This camera enables the implementation of the test following IEC TS 600904-13:2018 [68] indications. 


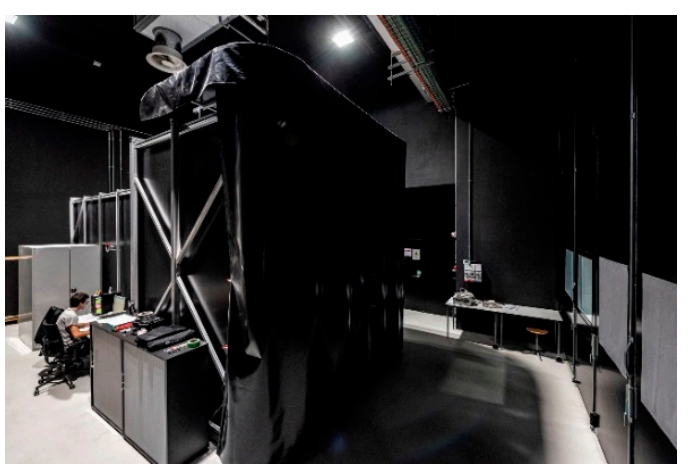

(a)

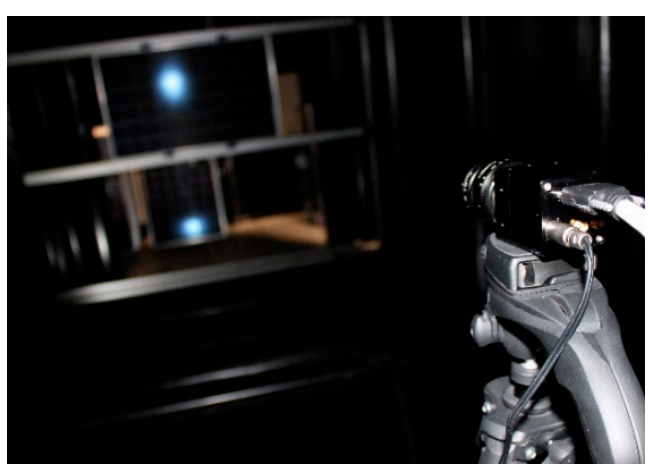

(b)

Figure 3. Indoor "Solare PV Lab": (a) panoramic view of solar simulator room; and (b) electroluminescence test execution.

\subsection{Indoor Testing of BIPV Technologies: First Results}

From the market analysis described in Section 4.1, two modules typologies have been selected to be tested through indoor and outdoor laboratories. The tests described hereafter constitute the first experimental campaign on coloured BIPV products. The first set of chosen modules belong to the Suncol ${ }^{\circledR}$ Tile technology, provided by Glassfer \& Sunage, and consist in a sandwich PV panel of two tempered solar glass sheets within which a layer of monocrystalline cells is laminated by means of polymeric encapsulant films. The two sets of modules differ in dimensions, number of cells and customisation of the coloured front glass. The detail of the two modules typologies is given in Table 2, while Figure 4 shows the modules' samples. These modules have been selected for their high flexibility and aesthetical integration for architecturally sensitive areas, as explained in Section 4.1. Two different customisation techniques have been selected to compare their aesthetic impact and their energy performance: one has a full colour tinted front glass and one has a printed tile pattern. In both cases, an anti-reflection coating has been applied on solar cells. Furthermore, the modules are provided with an invisible mounting system and module frame that guarantees the reduction of the visual disturbance as well as their reversibility.

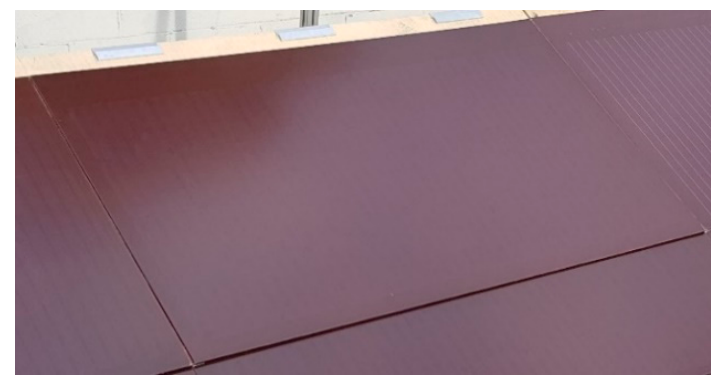

(a)

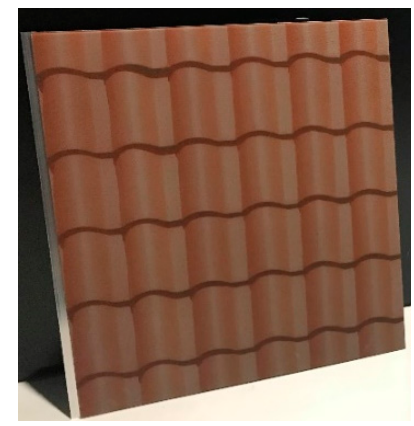

(b)

Figure 4. Tested modules samples: Suncol ${ }^{\circledR}$ Tile-Terracotta Simil RAL 8015 (a); and Suncol ${ }^{\circledR}$ Tile-Texturing Simil roof tile (b).

Table 2. Detail of the two tested modules typologies.

\begin{tabular}{ccc}
\hline & Suncol $^{\circledR}$ Tile-Terracotta & Suncol $^{\circledR}$ Tile-Texturing \\
\hline Solar tempered front glass & Simil RAL 8015 & Simil roof tile \\
Active layer & 18 monocrystalline cells & 36 monocrystalline cells \\
Solar tempered back glass & Black printed & Black printed \\
Dimensions $[\mathrm{m} \times \mathrm{m}]$ & $1 \times 0.575$ & $1 \times 1.05$ \\
\hline
\end{tabular}


The integration of solar cells into coloured modules could results in losses in the irradiance reaching the solar cell within the module, since the colours and materials used in the glass modification have an impact on glass transmittance and light spectrum reaching the underlying cells. Some studies investigated the influence that coloured layers could have in the energy performance of c-Si PV modules, with both theoretical and experimental analyses [44,45]. One main result of these studies is that usually the theoretical colour-related power losses are lower than the actual ones, due to undesired reflections in the near infrared spectrum (NIR, wavelengths $>780 \mathrm{~nm}$ ) that could appear. Therefore, as a first analysis for the characterisation of the two selected technologies, we decided to investigate the energy parameters of the two modules' set, with the aim of evaluating the power losses due to the front glass modification. The expected power loss due to the variations in the optical properties is analysed through the cell-to-module $\left(C T M_{x}\right)$ factor (Equation (1)), where $X$ is the considered electrical parameter:

$$
\text { CTM }_{x}=\frac{X_{\text {module }}}{\sum_{i=1}^{n} X_{\text {cell }, i}}
$$

This ratio is calculated using the electrical parameters of the bare cells before the assembly of the module. To calculate the CTM factor, firstly the electric performance of the two modules typologies in standard test conditions have been investigated in the indoor laboratory, with the solar simulator. The results present a normal shape of the current-voltage curves (Figure 5). The electrical parameters obtained in the standard test conditions (STC) performance test are presented in Table 3, where the power at maximum point $\left(\mathrm{P}_{\mathrm{mpp}}\right)$, short-circuited current $\left(\mathrm{I}_{\mathrm{sc}}\right)$ and open voltage $\left(\mathrm{V}_{\mathrm{oc}}\right)$ are highlighted. Regarding the maximum power linearity respect to irradiance levels at $100-1000 \mathrm{~W} / \mathrm{m}^{2}$, the test shows acceptable performances comparable to those in commercial transparent glass photovoltaic modules (Figure 6).

Table 3. Electrical parameters at standard test conditions of the tested module at maximum power point $\left(\mathrm{P}_{\mathrm{mpp}}\right)$; current at maximum power point $\left(\mathrm{I}_{\mathrm{mpp}}\right)$; voltage at maximum power point $\left(\mathrm{V}_{\mathrm{mpp}}\right)$; open circuit voltage $\left(\mathrm{V}_{\mathrm{oc}}\right)$; and short-circuit current $\left(\mathrm{I}_{\mathrm{sc}}\right)$.

\begin{tabular}{cccccc}
\hline & $\mathbf{P}_{\mathbf{m p p}}(\mathbf{W})$ & $\mathbf{I}_{\mathbf{m p p}}(\mathbf{A})$ & $\mathbf{V}_{\mathbf{m p p}}(\mathbf{V})$ & $\mathbf{V}_{\mathbf{o c}}(\mathbf{V})$ & $\mathbf{I}_{\mathbf{s c}}(\mathbf{A})$ \\
\hline Suncol $^{\circledR}$ Tile Terracotta & 77 & 8.49 & 9.8 & 12.06 & 8.3 \\
Suncol $^{\circledR}$ Tile Texturing Roof tile & 133.6 & 6.71 & 19.9 & 23.96 & 7.19 \\
\hline
\end{tabular}

Table 4 provides CTM factors for both the types of PV modules and a reference monocrystalline module with clear front glass. The results show power losses in accordance with those calculated by Peharz and Ulm [45] using a numerical model for RAL colours between 8000 and 8050, which is about $-21 \%$ in comparison with zero reflective devices. We obtained $-20.7 \%$ for Suncol ${ }^{\circledR}$ Tile Terracotta and $31.2 \%$ for Suncol ${ }^{\circledR}$ Tile Texturing Roof tile. Thus, our test shows agreement with the numerical model for the PV modules of uniform terracotta colour. These performance losses are expected: they depend on the layers superposed to the c-Si cells (EVA polymeric encapsulant and glass pane) and solar cells and strings interconnection. This behaviour is enhanced by the colours and ceramic ink used to customise the modules' front glass pane which hinders the PV performance, due to the optical and physical behaviour of the coloured layers, that depends on the modules' hue and coverage percentage $[65,66]$.

Table 4. CTM loss in Suncol ${ }^{\circledR}$ Tile Terracotta and Texturing Roof tile modules.

\begin{tabular}{cccc}
\hline CTM Loss & $\mathbf{P}_{\text {mpp }}(\mathbf{W})$ & $\mathbf{I}_{\mathbf{s c}}(\mathbf{A})$ & $\mathbf{V}_{\mathbf{o c}}(\mathbf{V})$ \\
\hline Suncol $^{\circledR}$ Tile Terracotta & $-20.7 \%$ & $-17.4 \%$ & $-0.60 \%$ \\
$\begin{array}{c}\text { Suncol } \\
{ }^{\circledR}\end{array}$ & $-31.2 \%$ & $-28.4 \%$ & $-1.30 \%$ \\
Tile Texturing Roof tile & -3.8 & -4.1 & - \\
module [69] & & & \\
\hline
\end{tabular}


As a further analysis, we provide hereafter the results of electroluminescence control technique, which is increasingly relevant in the analysis of PV modules quality. It basically shows the path taken by the electrons along the circuitry in the module. Several issues can be detected such as diverse mechanical breaks in cells or disconnected areas. The test was realised with a VIS-SWIR InGaAs camera and focused on the effect of the non-transparent glass in the EL signal emission from the module; therefore, from normal to near $0^{\circ}$ incidence shooting was carried out in the indoor lab (Figure 7). The first results in normal incidence demonstrate a good reception of the signal compared to transparent glass technology (Figure 8). For small angles of incidence, no blind spot has been detected in both types of modules and the transmission of the EL signal is still acceptable. Thus, the results of the EL test show a good electrical response of the modules regardless the incident angle of the radiation. This is a critical aspect when performing outdoor operation and maintenance (O\&M) activities in real installations where the position of the panel can be diverse depending on the building and limitations for shooting can be multiple (Figure 9).

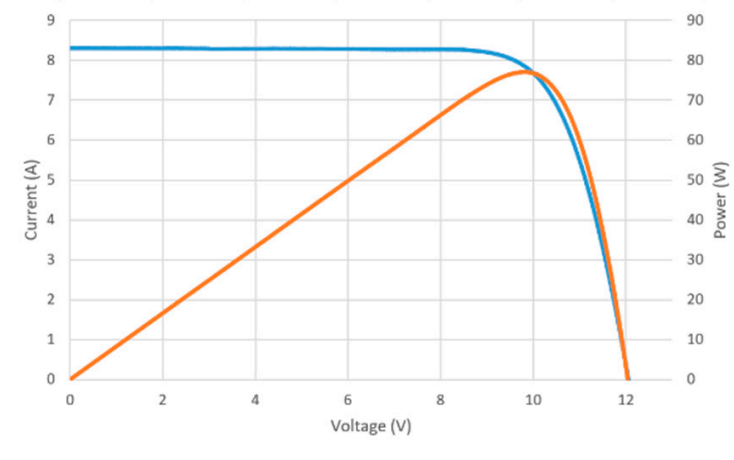

(a)

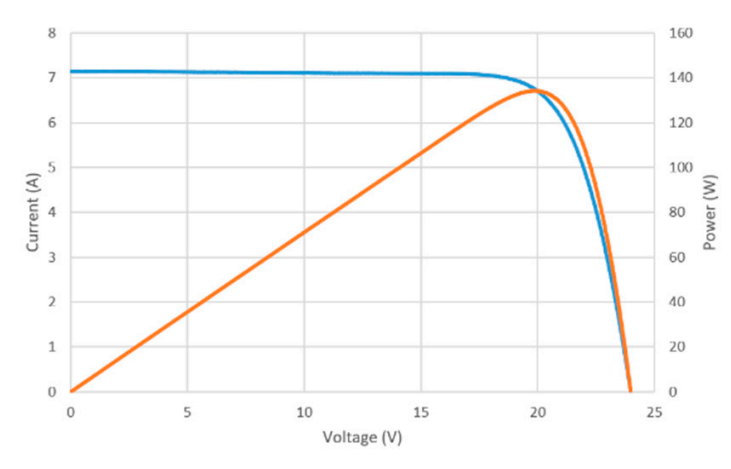

(b)

Figure 5. STC performance of PV modules under analysis: (a) Suncol ${ }^{\circledR}$ Tile Terracotta; and (b) Suncol ${ }^{\circledR}$ Tile Texturing Roof tile.

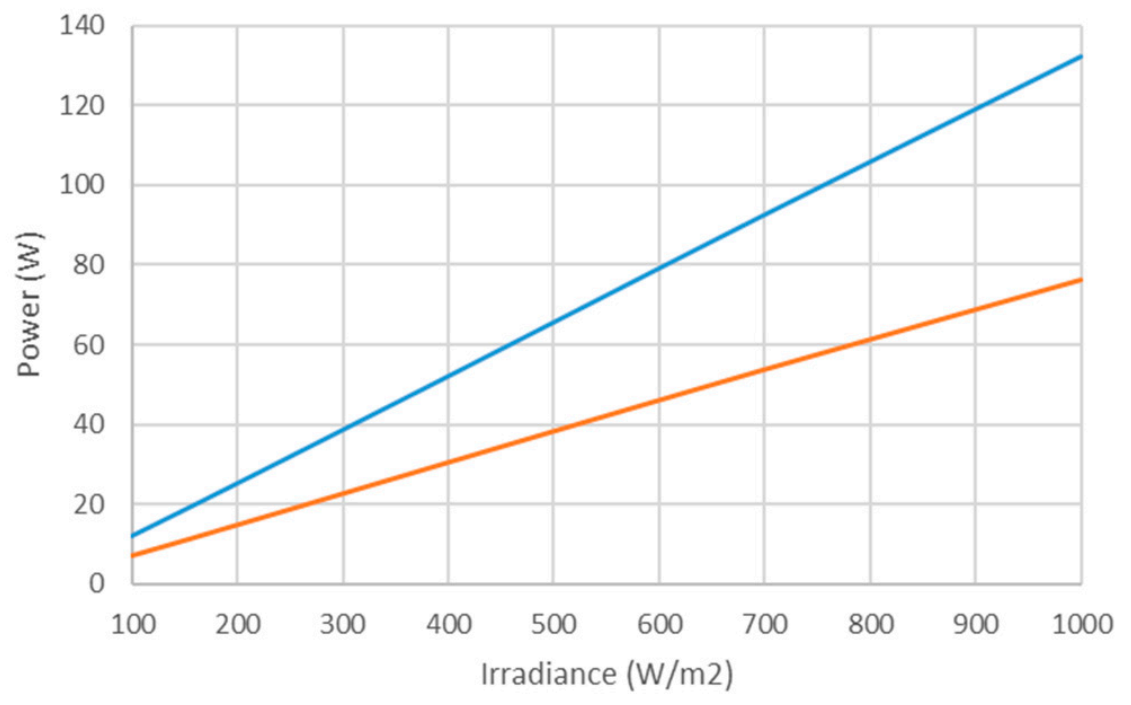

- P-G Sunage Texturing Tegola _ P-G Sunage Terracotta

Figure 6. Power at maximum point according to different irradiance levels. 


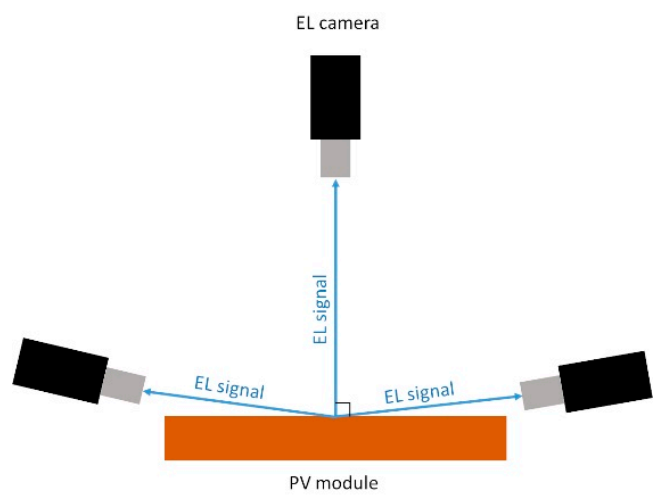

Figure 7. Electroluminescence test at different shooting angles.

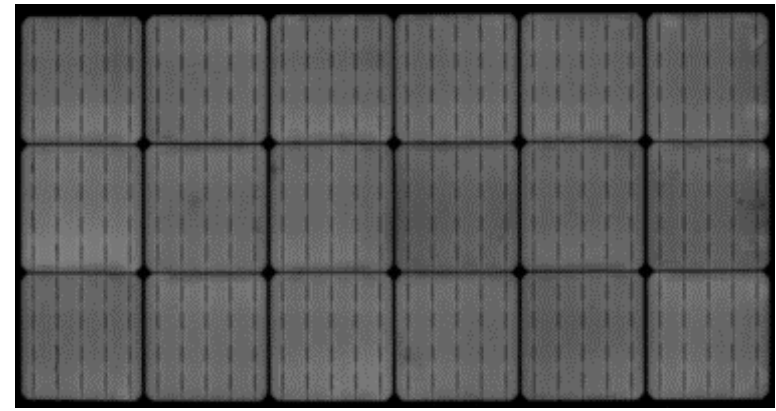

(a)

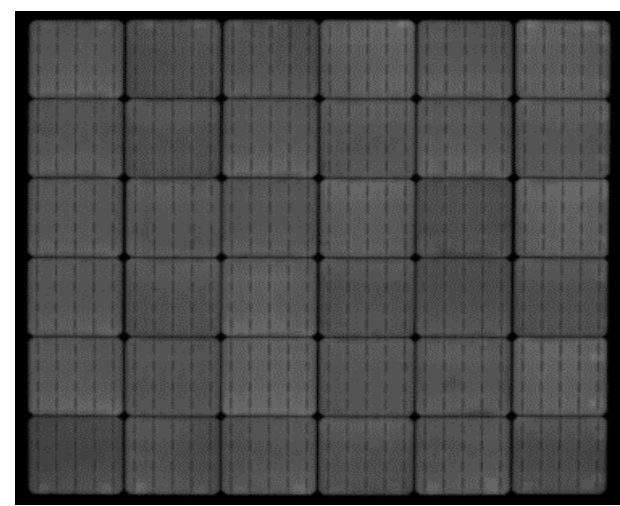

(b)

Figure 8. Electroluminescence images obtained at normal incidence shooting for: (a) Terracotta; and (b) Texturing Roof Tile.

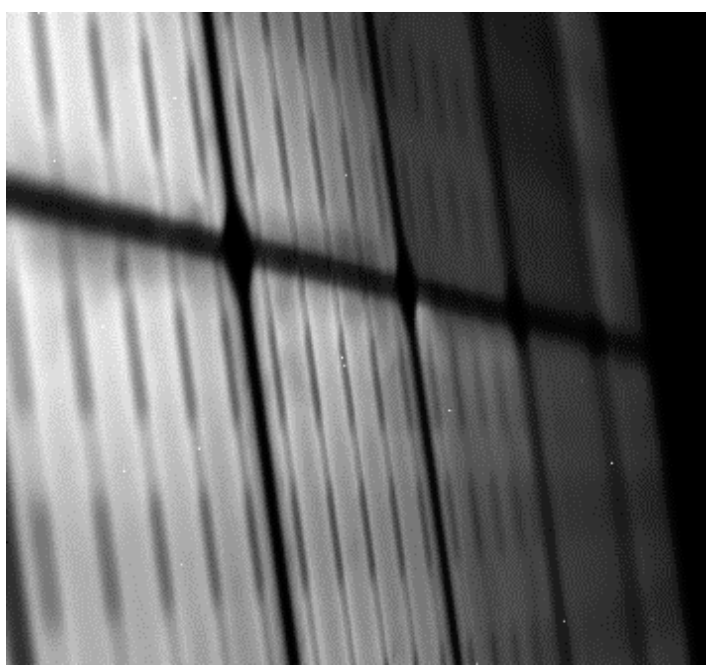

(a)

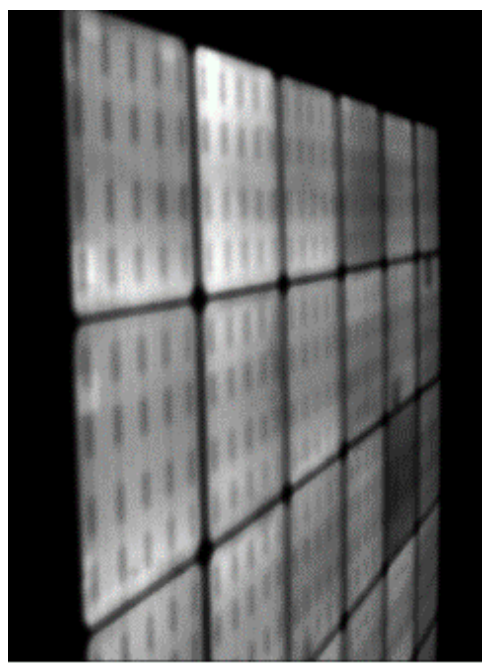

(b)

Figure 9. Electroluminescence images obtained at small incidence shooting for: (a) Terracotta; and (b) Texturing roof Tile.

\subsection{Experimental Design of Outdoor Testing}

The roof testbed described in Section 5.1.1 is conceived with an interdisciplinarity approach focusing on the three integration aspects mentioned in Section 3 (technology, aesthetic and energy). This interdisciplinarity approach makes it unique with respect to other existing BIPV outdoor 
setups described in [70] that provides an overview of the existing international BIPV R\&D testing facilities. Indeed, the proposed experimental set up is not conceived for testing stand-alone modules performance but rather a large portion of envelope BIPV systems, offering the opportunity to investigate the aesthetical and technological integration of real scale installations, involving several modules. The added value of this kind of testbed is that it will offer the opportunity to different stakeholders in the BIPV community (students, designers and the public and heritage authorities involved in the energy issues) to witness first-hand innovative BIPV technologies, better understanding the benefits of coloured PV systems.

A first qualitative study has been performed on the aesthetic integration and technical compatibility. The ensemble of PV modules are inserted to minimise their visual impact, guaranteeing: (i) 100\% coverage of the roof surface; (ii) aesthetic and chromatic integration with traditional clay roof tiles (the selection terra-cotta colour, both with and without the texturing pattern); (iii) geometrical and chromatic uniformity inserting two different kinds of PV parallels in parallel rows; (iv) coplanarity with the roof line; (v) colour rendering under different exposure and tilting conditions; and (vi) pattern continuity for the tile texturing PV cells. Furthermore, the PV modules are integrated into the roof testbed through a back attached tile-type mounting system that guarantees successful integration from the aesthetical point of view since no mounting system or module frame is disturbing visual appearance (Figure 10). Considering the technology integration, technical compatibility and system reversibility are evaluated. Technical compatibility refers mainly to the reduction of moisture accumulation on the backside of the panels, while reversibility refers to the use of mounting systems to remove the panels without affecting the integrity of the roof. Figure 11 shows the roof layout (Figure 11a) and its electrical configuration (Figure 11b). From a qualitative point of view, the testbed design has been conducted with particular focus to the functional requirements for the roof outer layers, such as water resistance and moisture accumulation prevention. The first qualitative findings show no accumulation of water or moisture problems to appear. Quantitative measurements will be provided in future works to rigorously evaluate the technology performance in this respect. Moreover, the back attached tile-type mounting system guarantees the reversibility of the system without affecting the original roof, as requested for the preservation of heritage systems.

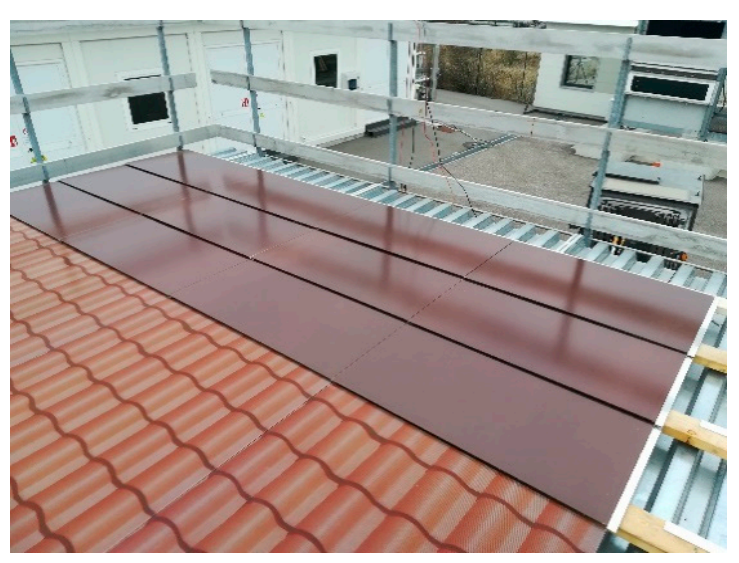

(a)

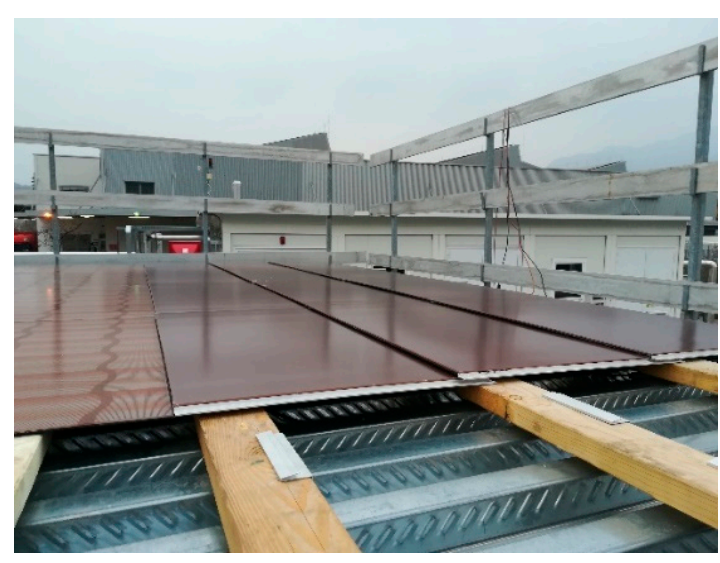

(b)

Figure 10. Testbed realisation on the outdoor roof testbed. To perform quantitative tests, the two module types Suncol ${ }^{\circledR}$ Terracotta and Suncol ${ }^{\circledR}$ Texturing Roof Tile are connected in two strings to a multi-string (two maximum power point trackers) grid-connected inverter. PT100 temperature sensors are applied on the backside of eight modules, as displayed in Figure 10b. 


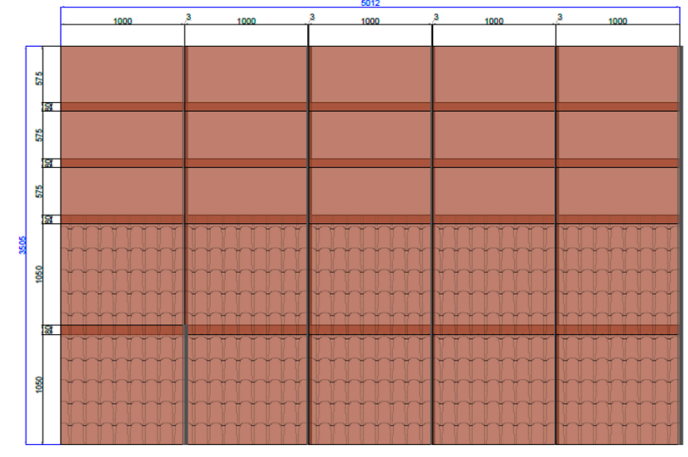

(a)

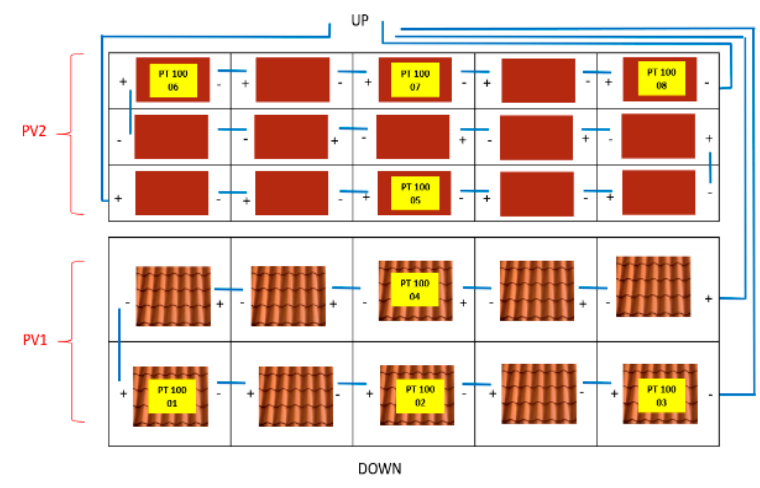

(b)

Figure 11. Testbed design: (a) roof layout; and (b) electrical configuration.

\section{Conclusions}

This paper outlines the research activities carried out to define the configuration of new testbeds for the experimental characterisation of coloured BIPV technologies. The investigation of BIPV technology is an interdisciplinary activity that calls for heterogeneous expertise, having the BIPV modules multifunctional features related to the aesthetic and technological integration in building envelope and to energy integration both in the building systems and in the electric grid. Being BIPV applications tailored on the building envelopes, the modules and the mounting systems require a specific design. This high level of customisation constitutes the strength and the uniqueness of BIPV products but also a limit, since it hinders the series production of the modules and, thus, it limits their cost reduction. Furthermore, the customisation of coloured BIPV modules that completely hide the PV cells from the view and their expansion on the market would contribute in enhancing the social acceptance of PV in sensitive areas, where the PV technologies have been often considered anaesthetic, and thus unacceptable, by users and architects. Therefore, there is the need to overcome the technical, social and economic barriers to reach a larger scale of BIPV applications and thus improve their economic profitability. The first issue to deal with is the definition of the concept of integration, which needs to find a unique expression within BIPV literature and standards. The definition of the criteria that set the application of BIPV in architecturally sensitive areas need especially to be revised. In fact, the existing guidelines refer mainly to PV systems applied on the building envelope (BAPV), without considering the actual potential of the modern coloured BIPV technologies that can "disappear" from the view. Secondly, it is important to better investigate the wide range of available technologies for coloured BIPV, with regards to the electrical behaviour of a large variety of coloured modules. This variety results in a fragmented market scenario where several customisation options are now available. Nonetheless, the customisation process could lead to modifications in the electrical behaviour of the module, due to the presence of one or more coloured layers which cause the reflection or absorption of a portion of the solar spectrum (in the visible range) that would otherwise be converted into electricity, causing a reduction in the modules' yield.

Therefore, to deeply investigate this behaviour, experimental assessment is needed both at STC and under real operating conditions on final assembled BIPV modules. For this reason, we selected two BIPV modules to be tested in EURAC Research's indoor and outdoor facilities. Indoor tests are already completed with satisfactory results and will support outdoor experiment analysis. Besides the technical assessment, real scale BIPV testbeds are useful to test different solution for the mounting systems and to understand the risks related to the installation of BIPV modules. Testbeds are also important because they could show different stakeholders the new and concrete aesthetic and technical possibilities of BIPV systems, improving the users' trust on aesthetic integration, the market penetration and the economic profitability. In fact, BIPV products could sensibly expand the envelope surfaces available for PV installation. As a result, BIPV could lead to a shift in the energy paradigm for buildings that 
would no longer be a mere energy consumer in the local electric grid, but could indeed provide load flexibility by producing, storing and selling electricity to the grid according to mutual needs. To achieve the objectives of deeper market penetration and higher economic profitability of BIPV applications, further test activities will be carried out in these facilities. In fact, several BIPV systems (including PV modules, substructures and energy systems) will be integrated in both the outdoor roof and façade testbed, with the aim of testing and comparing them with respect to the three integration aspects of aesthetic, technology and energy, since all these aspects are of fundamental importance to enhance the application of BIPV technologies in the built environment.

Author Contributions: Conceptualisation, M.P., E.L. and L.M.; methodology, M.P.; investigation, M.P., E.L., L.M. and A.A.; resources, M.P. and M.L.; writing—original draft preparation, M.P. and E.L.; writing-review and editing, M.P., E.L., L.M., A.A. and F.C.; visualisation, M.P.; and project administration, L.M. All authors have read and agreed to the published version of the manuscript.

Funding: The research leading to these results received funding from the Institute for Renewable Energy of Eurac Research, within the project "BIPV UPpeal". In addition, this research was co-financed by the European Union, European Regional Development Fund, the Italian Government, the Swiss Confederation and Cantons, as part of the Interreg V-A Italy-Switzerland Cooperation Program, within the context of the "BIPV meets History! project (grant No. 603882), for the definition of criteria and products for BIPV integration in architecturally sensitive areas. Furthermore, the research received funding from the Program EFRE/FESR Provincia autonoma di Bolzano-Alto Adige 2014-2020, under Project number FESR1042, "Studio dell'integrazione di reti elettriche e termiche con la flessibilità energetica degli edifici-INTEGRIDS", for the purchasing of the inverter, connection and distribution boxes. Finally, it has received funding from the Program EFRE/FESR Provincia autonoma di Bolzano-Alto Adige 2014-2020, under Project number FESR1128, "Use of Industry 4.0 and Internet of Things logics in the photovoltaic sector-PV 4.0", for the purchasing of PT100 temperature sensors.

Acknowledgments: We acknowledge David Moser and Alexandra Troi for the revision and the useful suggestions on the paper structure; Gazmend Luzi for the data provided on PV cells; and Ilaria Alberti for the revision of English text.

Conflicts of Interest: The authors declare no conflict of interest.

\section{References}

1. EC Clean Energy for All Europeans. Clean Energy for All Europeans; European Commission: Brussels, Belgium, 2008; Available online: https://ec.europa.eu/energy/topics/energy-strategy/clean-energy-all-europeans_en (accessed on 5 April 2020).

2. United Nation Framework Convention on Climate Change in 21st Conference of the Parties Paris Agreement; UNFCC: Paris, France, 2015.

3. European Parlament. DIRECTIVE (EU) 2018/844. Energy Performance of Buildings; European Parlament: Brussels, Belgium, 2018.

4. European Parlament. DIRECTIVE (EU) 2018/2002 on Energy Efficiency; European Parlament: Brussels, Belgium, 2018.

5. European Parlament. DIRECTIVE (EU) 2018/2001 on the Promotion of the Use of Energy from Renewable Sources; European Parlament: Brussels, Belgium, 2018.

6. Jensen, S.Ø.; Marszal-Pomianowska, A.; Lollini, R.; Pasut, W.; Knotzer, A.; Engelmann, P.; Stafford, A.; Reynders, G. IEA EBC annex 67 energy flexible buildings. Energy Build. 2017, 155, 25-34. [CrossRef]

7. Michas, S.; Stavrakas, V.; Spyridaki, N.-A.; Flamos, A. Identifying research priorities for the further development and deployment of solar photovoltaics. Int. J. Sustain. Energy 2019, 38, 276-296. [CrossRef]

8. Zhang, T.; Wang, M.; Yang, H. A Review of the energy performance and life-cycle assessment of building-integrated photovoltaic (BIPV) systems. Energies 2018, 11, 3157. [CrossRef]

9. Eder, G.; Peharz, G.; Trattnig, R.; Bonomo, P.; Saretta, E.; Frontini, F.; Polo López, C.S.; Rose Wilson, H.; Eisenlohr, J.; Martin Chivelet, N.; et al. Coloured BIPV-Market, Research and Development; International Energy Agency: Paris, France, 2019; Volume 60.

10. Chang, R.; Cao, Y.; Lu, Y.; Shabunko, V. Should BIPV technologies be empowered by innovation policy mix to facilitate energy transitions?-Revealing stakeholders' different perspectives using Q methodology. Energy Policy 2019, 129, 307-318. [CrossRef] 
11. Heinstein, P.; Ballif, C.; Perret-Aebi, L.-E. Building integrated photovoltaics (BIPV): Review, potentials, barriers and myths. Green 2013, 3, 125-156. [CrossRef]

12. Freitas, S.; Brito, M.C. Solar façades for future cities. Renew. Energy Focus 2019, 31, 73-79. [CrossRef]

13. Escarre, J.; Li, H.Y.; Sansonnens, L.; Galliano, F.; Cattaneo, G.; Heinstein, P.; Nicolay, S.; Bailat, J.; Eberhard, S.; Ballif, C.; et al. When PV modules are becoming real building elements: White solar module, a revolution for BIPV. In Proceedings of the 2015 IEEE 42nd Photovoltaic Specialist Conference (PVSC), New Orleans, LA, USA, 14-19 June 2015; pp. 1-2.

14. Saretta, E.; Bonomo, P.; Frontini, F. Active BIPV glass facades: Current trends of innovation. In Proceedings of the GPD Glass Performance Days 2017, Tampere, Finland, 28-30 June 2017.

15. IEA-PVPS Task 7 Photovoltaic Power Systems in the Built Environment. Available online: https://iea-pvps. org/research-tasks/photovoltaic-power-systems-in-the-built-environment/ (accessed on 14 June 2020).

16. PV Accept. Available online: http://www.pvaccept.de (accessed on 5 June 2020).

17. 3ENCULT: Efficient Energy for EU Cultural Heritage. Available online: http://www.3encult.eu/en/project/ welcome/default.html (accessed on 5 June 2020).

18. EFFESUS: Energy Efficiency for EU Historic Districts' Sustainability. Available online: http://www.effesus.eu (accessed on 5 June 2020).

19. BIPV Meets History: Value-Chain Creation for the Building Integrated Photovoltaics in the Energy Retrofit of Transnational Historic Buildings. Available online: http://www.bipvmeetshistory.eu (accessed on 6 June 2020).

20. Lovati, M.; Salvalai, G.; Fratus, G.; Maturi, L.; Albatici, R.; Moser, D. New method for the early design of BIPV with electric storage: A case study in northern Italy. Sustain. Cities Soc. 2019, 48, 101400. [CrossRef]

21. Huang, P.; Lovati, M.; Zhang, X.; Bales, C.; Hallbeck, S.; Becker, A.; Bergqvist, H.; Hedberg, J.; Maturi, L. Transforming a residential building cluster into electricity prosumers in Sweden: Optimal design of a coupled PV-heat pump-thermal storage-electric vehicle system. Appl. Energy 2019, 255, 113864. [CrossRef]

22. Maturi, L.; Belluardo, G.; Moser, D.; Del Buono, M. BiPV system performance and efficiency drops: Overview on PV module temperature conditions of different module types. Energy Procedia 2014, 48, 1311-1319. [CrossRef]

23. Davis, M.W.; Fanney, A.H.; Dougherty, B.P. Measured Versus predicted performance of building integrated photovoltaics. J. Sol. Energy Eng. 2003, 125, 21-27. [CrossRef]

24. BSI. EN 50583-1:2016. Photovoltaics in Buildings. BIPV Modules; BSI: Brussels, Belgium, 2016.

25. European Parliament and European Council. Regulation (EU) No 305/2011; European Parliament and European Council: Brussels, Belgium, 2011.

26. Farkas, K.; Frontini, F.; Maturi, L.; Munari Probst, M.C.; Roecker, C.; Scognamiglio, A.; Zanetti, I. T.41.A.2: Solar Energy Systems in Architecture-Integration Criteria and Guidelines Subtask A: Criteria for Architectural Integration; International Energy Agency: Paris, France, 2012.

27. IEA-SHC T59 Deep Renovation of Historic Buildings towards Lowest Possible Energy Demand and $\mathrm{CO}_{2}$ Emission (nZEB). Available online: http://task59.iea-shc.org (accessed on 10 May 2020).

28. IEA-SHC T51 Solar Energy in Urban Planning. Available online: http://task51.iea-shc.org/ (accessed on 10 May 2020).

29. Franco, G.; Magrini, A. Historical Buildings and Energy; Springer International Publishing: Cham, Switzerland, 2017; ISBN 978-3-319-52613-3.

30. Maturi, L.; Adami, J. Building Integrated Photovoltaic (BIPV) in Trentino Alto Adige; Green Energy and Technology; Springer International Publishing: Cham, Switzerland, 2018; ISBN 978-3-319-74115-4.

31. European Union's Horizon 2020 Project EnergyMatching. Available online: https://www.energymatching.eu/ (accessed on 15 June 2020).

32. Scotland, H. Micro-Renewables in the Historic Environment; Historic Scotland: Edinburgh, UK, 2014.

33. Wohlleben, M.; Moeri, S.; Müller, N.; Schletti, B. Energieeffizienz am Baudenkmal: Solarenergie; Kantonale Denkmalpflege Bern und Kantonale Denkmalpflege: Bern-Zürich, Switzerland, 2014.

34. Polo López, C.S.; Lucchi, E.; Franco, G. Acceptance of Building Integrated Photovoltaic (BIPV) in Heritage Buildings and Landscapes: Potentials, Barrier and Assessment Criteria; REHABEND: Granada, Spain, 2020; pp. 1-8.

35. National Renewable Energy Laboratory-National Trust for Historic Preservation. Implementing Solar Photovoltaic Projects on Historic Buildings and in Historic Districts; National Renewable Energy Laboratory: Golden, CO, USA, 2011; Volume 1. 
36. Repubblica e Cantone Ticino. Interventi Nei Nuclei Storici. Criteri di Valutazione Paesaggistica Nell'ambito Della Procedura Edilizia; Repubblica e Cantone Ticino: Bellinzona, Switzerland, 2016.

37. Dipartimento Federale Dell'interno (DFI). Cultura Solare. Conciliare Energia Solare e Cultura Della Costruzione; DFI: Bern, Switzerland, 2019.

38. Dipartimento Federale Dell'interno (DFI). Energia e Monumento; DFI: Bern, Switzerland, 2018.

39. Ministero per i Beni e le Attività Culturali (MiBACT). Linee di Indirizzo per il Miglioramento Dell'efficienza Energetica del Patrimonio Culturale: Architettura, Centri e Nuclei Storici ed Urbani; MiBACT: Roma, Italy, 2015.

40. Changeworks. Renewable Heritage. A Guide to Microgeneration in Traditional and Historic Homes; Changeworks: Edinburgh, UK, 2009.

41. Achenza, M.; Desogus, G. Guidelines on Building Integration of Photovoltaic in Mediterranean Area; UNICA-DICAAR: Cagliari, Italy, 2013.

42. Scognamiglio, A.; Berni, F.; Frontini, C.S.P.L.; Maturi, L. The complex dialogue between photovoltaics and pre-existing: Starting point for a discussion. In Proceedings of the 27th European Photovoltaic Solar Energy Conference and Exhibition, Frunkfurt, Germany, 24-28 September 2012; pp. 4161-4168.

43. Bellazzi, A.; Belussi, L.; Meroni, I. Estimation of the performance of a BIPV façade in working conditions through real monitoring and simulation. Energy Procedia 2018, 148, 479-486. [CrossRef]

44. Røyset, A.; Kolås, T.; Jelle, B.P. Coloured building integrated photovoltaics: Influence on energy efficiency. Energy Build. 2020, 208, 109623. [CrossRef]

45. Peharz, G.; Ulm, A. Quantifying the influence of colors on the performance of c-Si photovoltaic devices. Renew. Energy 2018, 129, 299-308. [CrossRef]

46. Jolissaint, N.; Hanbali, R.; Hadorn, J.C.; Schüler, A. Colored solar façades for buildings. Energy Procedia 2017, 122, 175-180. [CrossRef]

47. IEA PVPS Task 15 Subtask E. Report T15-07-Coloured BIPV Market, Research and Development; IEA: Paris, France, 2019.

48. El amrani, A.; Menous, I.; Mahiou, L.; Tadjine, R.; Touati, A.; Lefgoum, A. Silicon nitride film for solar cells. Renew. Energy 2008, 33, 2289-2293. [CrossRef]

49. Li, M.; Zeng, L.; Chen, Y.; Zhuang, L.; Wang, X.; Shen, H. Realization of Colored Multicrystalline Silicon solar cells with $\mathrm{SiO}_{2} / \mathrm{SiN}_{x}: \mathrm{H}$ double layer antireflection coatings. Int. J. Photoenergy 2013, 2013, 1-8. [CrossRef]

50. Chen, Y.; Yang, Y.; Feng, Z.; Altermatt, P.P.; Shen, H. Color modulation of c-Si solar cells without significant current-loss by means of a double-layer anti-reflective coating. In Proceedings of the 27th European Photovoltaic Solar Energy Conference and Exhibition, Frunkfurt, Germany, 24-28 September 2012; pp. 2014-2016.

51. Ji, C.; Zhang, Z.; Masuda, T.; Kudo, Y.; Guo, L.J. Vivid-colored silicon solar panels with high efficiency and non-iridescent appearance. Nanoscale Horiz. 2019, 4, 874-880. [CrossRef]

52. Pascual-San José, E.; Sánchez-Díaz, A.; Stella, M.; Martínez-Ferrero, E.; Alonso, M.I.; Campoy-Quiles, M. Comparing the potential of different strategies for colour tuning in thin film photovoltaic technologies. Sci. Technol. Adv. Mater. 2018, 19, 823-835. [CrossRef]

53. Calvo, M.E. Materials chemistry approaches to the control of the optical features of perovskite solar cells. J. Mater. Chem. A 2017, 5, 20561-20578. [CrossRef]

54. Kim, Y.; Son, J.; Shafian, S.; Kim, K.; Hyun, J.K. Semitransparent blue, green, and red organic solar cells using color filtering electrodes. Adv. Opt. Mater. 2018, 6, 1-10. [CrossRef]

55. Sehati, P.; Malmros, I.; Karlsson, S.; Kovacs, P.; Kovacs, P. Aesthetically Pleasing PV Modules for the Built Environment; RISE Research Institutes of Sweden AB: Växjö, Sweden, 2019.

56. Eastman Vanceva Rethink Color-Colored PVB Interlayer Brochure. Available online: https://www.vanceva. com/sites/default/files/pictures/ai-arch-3146_vanceva_brochure.pdf (accessed on 12 June 2020).

57. Onyx Solar Onyx Technical Guide. Available online: http://onyxsolardownloads.com/docs/ALL-YOU-NEED/ Technical_Guide.pdf (accessed on 12 June 2020).

58. Wittkopf, S. Building integrated photovoltaic at NEST-Preliminary test bedding results. J. Phys. Conf. Ser. 2019, 1343, 012090. [CrossRef]

59. UNI 8290-Edilizia Residenziale. Sistema Tecnologico. Classificazione e Terminologia; Ente Nazionale Italiano di Unificazion n(UNI): Milano, Italy, 1981.

60. H2020 PV IMPACT. Available online: https://pvimpact.eu/ (accessed on 29 July 2020). 
61. Green, M.A.; Dunlop, E.D.; Hohl-Ebinger, J.; Yoshita, M.; Kopidakis, N.; Hao, X. Solar cell efficiency tables (version 56). Prog. Photovoltaics Res. Appl. 2020, 28, 629-638. [CrossRef]

62. Dunlop, E.D.; Halton, D.; Ossenbrink, H.A. 20 years of life and more: Where is the end of life of a PV module? In Proceedings of the Conference Record of the Thirty-first IEEE Photovoltaic Specialists Conference, Lake Buena Vista, FL, USA, 3-7 January 2005; pp. 1593-1596.

63. Virtuani, A.; Caccivio, M.; Annigoni, E.; Friesen, G.; Chianese, D.; Ballif, C.; Sample, T.; Dunlop, E.D.; Halton, D.; Ossenbrink, H.A. 35 years of photovoltaics: Analysis of the TISO-10-kW solar plant, lessons learnt in safety and performance-Part 1. In Proceedings of the Conference Record of the 46th IEEE Photovoltaic Specialists Conference, Chicago, IL, USA, 16-21 June 2019; Volume 27, pp. 328-339.

64. Tzikas, C.; Valckenborg, R.M.E.; Dörenkämper, M.; van den Donker, M.; Lozano, D.D.; Bognár, Á.; Loonen, R.; Hensen, J.; Folkerts, W. Outdoor characterization of colored and textured prototype PV facade elements. In Proceedings of the 35th European Photovoltaic Solar Energy Conference and Exhibition, Brussels, Belgium, 24-27 September 2018.

65. IEC. 60904-9:2007 Photovoltaic Devices_Part 9: Solar Simulator Performance Requirements; IEC: Geneva, Switzerland, 2007; p. 30.

66. UNI CEI EN ISO/IEC. 17025:2005-Requisiti Generali per la Competenza dei Laboratori di Prova e di Taratura; Ente Nazionale Italiano di Unificazion n(UNI): Milano, Italy, 2005.

67. IEC. 61215-1:2016-Terrestrial Photovoltaic (PV) Modules—Design Qualification and Type Approval_Part 1: Test Requirements; IEC: Geneva, Switzerland, 2016.

68. IEC TS. 60904-13:2018 Photovoltaic Devices-Part 13: Electroluminescence of Photovoltaic Modules; IEC: Geneva, Switzerland, 2018.

69. Haedrich, I.; Surve, S.; Thomson, A. Cell to module (CTM) ratios for varying industrial cell types. In Proceedings of the 2015 Asia Pacific Solar Research Conference, Melbourne, Australia, 30 November-2 December 2015; pp. 1-6.

70. EA-PVPS T15-02. BIPV Research Teams BIPV RED Facilities. An International Mapping; IEA-PVPS: Paris, France, 2017. 